\title{
BENTUK PERANAN GURU DALAM MEMBERIKAN PENDIDIKAN KEPEMIMPINAN
}

\author{
Hendra Riofita \\ Universitas Islam Negeri Sultan Syarif Kasim Riau, Indonesia \\ Email: hendrariofita@yahoo.com
}

\begin{abstract}
Indonesia, as many experts mention, has interminable problems of leadership. As a country in which Muslims are the majority, everyone should realize that all are born as a leader who shall have the responsibility upon people's welfare. But in reality, Indonesians are not wellbeing physically or spiritually. It absolutely defines that a leader should possess leadership knowledge to lead people, not only depend on the God's will solely. A leader is not an innate. For this purpose, teachers have the responsibility and important role to succeed the educational leadership as earlier as possible. This article is a descriptive discussion which is aimed at describing the roles of teacher as motivator, leader, problem solver and students' ally in modeling the leadership. The discussion shows that all the four roles of teachers give positive effect in gaining the learning objectives of educational leadership.
\end{abstract}

Keywords: motivator, leader, problem solver, educational leadership

\section{A. Pendahuluan}

Permasalahan yang terus dirasakan oleh masyarakat Indonesia dalam kehidupan berbangsa seperti tidak berkesudahan baik dalam hal politik, ekonomi, budaya, sosial dan bahkan dalam hal kehidupan beragama. Semua masalah tersebut seperti gelombang laut yang datang saling bergantian dan kadang bersamaan menerpa semua aspek kehidupan. Masalah seakan-akan adalah suatu keharusan yang mesti hadir dalam keseharian sebagai sebuah identitas dari sebuah bangsa besar yang bermasalah.

Banyak pakar dan para ahli yang sudah mencoba memberikan solusi terhadap berbagai masalah negeri ini, dan kedepan dipastikan akan terus lebih banyak lagi yang pada akhirnya banyak diantara mereka berpendapat bahwa permasalahan tersebut berhulu kepada permasalahan tentang kepemimpinan. Pemimpin yang tangguh diyakini akan menjadi problem solver yang hebat bagi semua permasalahan yang ada di bangsa ini. 
Indonesia mengalami krisis akan kepemimpinan, padahal sebagai bangsa yang beragama dan mayoritasnya penduduknya beragama Islam, kepemimpinan diyakini sebagai sebuah kodrat yang sudah menyatu kedalam kehidupan manusia semenjak manusia tersebut dilahirkan. Allah SWT berfirman dalam Surat Al-Baqarah ayat 30 sebagai berikut:

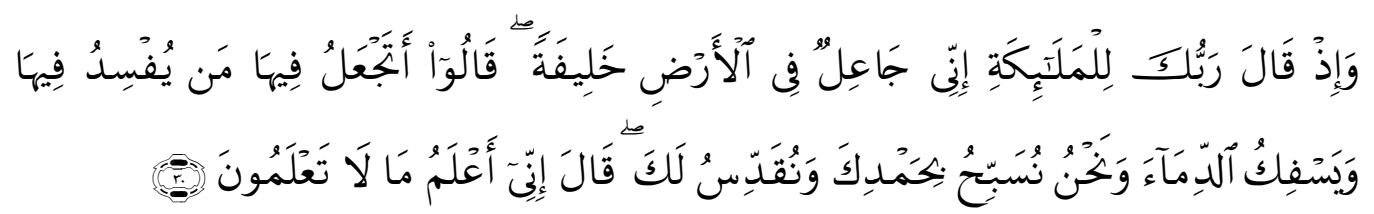

Artinya:

"Ingatlah ketika Tuhanmu berfirman kepada para Malaikat: "Sesungguhnya Aku hendak menjadikan seorang khalifah di muka bumi". Mereka berkata: "Mengapa Engkau hendak menjadikan (khalifah) di bumi itu orang yang akan membuat kerusakan padanya dan menumpahkan darah, padahal kami senantiasa bertasbih dengan memuji Engkau dan mensucikan Engkau?" Tuhan berfirman: "Sesungguhnya Aku mengetahui apa yang tidak kamu ketahui."

Jelaslah, bahwa ayat ini menjelaskan bahwa setiap manusia terlahir sebagai pemimpin dimana dalam kaitannya sebagai makhluk sosial, sebagai pemimpin, manusia tentunya harus dapat mensejahterakan manusia yang lain. Namun demikian, ketegasan ayat ini sepertinya belum mampu dimanifestasikan secara nyata oleh para pemimpin Indonesia saat ini, sehingga segala bentuk permasalahan seperti yang disampaikan diatas masih saja membelenggu masyarakat Indonesia. Padahal Hadis daripada Ibnu Amr R.A, Rasulullah SAW bersabda:

"Ketahuilah bahwa setiap kamu adalah pemimpin dan setiap kamu akan dipertanggungjawabkan atas kepimpinannya." (Hadis Muttafaq Alaih)

Jadi kepemimpinan dalam islam adalah sebuah amanah yang akan menetukan derajat seseorang disisi Allah SWT dan akan dimintai pertanggung jawabannya. Dengan demikian, siapapun yang menjadi pemimpin di Indonesia tentu diyakini telah menyadari tentang hal ini, sehingga dalam menjalankan amanah sebagai pemimpin harusnya selalu menjauhkan masyarakat dari segala bentuk permasalahan. Namun kenyataannya, setelah lebih kurang 71 tahun lepas dari masa penjajahan yang menyengsarakan, masyarakat Indonesia masih harus menerima kenyataan bahwa para pemimpin belum mampu membuat mereka dapat menikmati kemerdekaan itu dalam arti yang sesungguhnya yaitu 
sejahtera lahir dan batin, walaupun pemimpin di negeri ini telah berganti dari waktu ke waktu.

Allah SWT berfirman dalam Surat Yunus ayat 14 sebagai berikut:

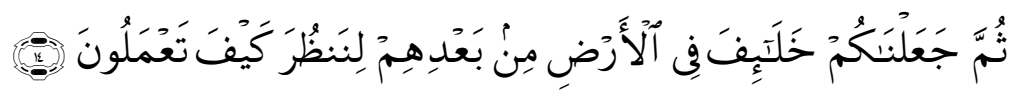

Artinya:

"Kemudian Kami jadikan kamu (Wahai umat Muhammad) khalifah-khalifah di bumi menggantikan mereka yang telah dibinasakan itu, supaya Kami melihat apa pula corak dan bentuk kelakuan yang kamu akan lakukan."

Jadi, berdasarkan firman tersebut, dapatlah dipahami bahwa siapapun yang menjadi pemimpin untuk menggantikan kepemimpinan yang telah berjalan, tetaplah dituntut bertanggung jawab dalam menjalankan amanahnya sebagai pemimpin untuk mensejahterakan masyarakat Indonesia lahir dan batin, tanpa harus menyalahkan keadaan ataupun orang lain, apalagi menyalahkan pemimpin yang sebelumnya.

Melihat kepada apa yang sudah disampaikan diatas dan kembali kepada kenyataan yang memperlihatkan bahwa kehidupan masyarakat Indonesia yang mayoritas belum sejahtera, maka tidaklah salah bila krisis kepemimpinan memang menjadi suatu masalah yang harus diatasi sesegera mungkin. Manusia Indonesia memang terlahir sebagai pemimpin, tetapi kodrat sebagai pemimpin saja terbukti tidak cukup untuk bisa memimpin Indonesia yang luas dan memiliki ratusan juta penduduk ini. Oleh karena itu, kepemimpinan haruslah diasah dan untuk mengasahnya memerlukan ilmu khususnya ilmu sebagai pemimpin.

Mengasah ilmu kepemimpinan kepada seseorang tentu sebaiknya dimulai sedini mungkin yaitu ketika usia masih belia sehingga kharakter kepemimpinan yang diinginkan bisa terbentuk dan terpatri sedari awal dan bisa diimplementasikan dalam perjalanan hidup yang dilalui pada segala kesempatan dan profesi yang dimiliki. Oleh sebab itu, peranan guru sedari awal untuk mencapai tujuan ini tentulah sangat menetukan. Gurulah yang meletakkan dasar-dasar bangunan kepemimpinan pada manusia Indonesia, karenanya, di era globalisasi, khususnya di masa kesepakatan Masyarakat Ekonomi Asean sudah diberlakukan, guru tidak lagi dituntut sekedar menjalankan profesi sebagai pendidik dan pengajar tetapi jauh dari pada itu guru harus 
bisa menjalankan berbagai peranan yang dapat menunjang keberhasilan siswa dalam berbagai aspek termasuk aspek kepemimpinan.

Berdasarkan gejala dan permasalahan yang disampaikan di atas, pada tulisan ini penulis ingin menyampaikan tentang 4 bentuk peranan yang dapat dilakukan oleh guru dalam memberikan pendidikan kepemimpinan bagi siswa, yaitu: (1) guru sebagai motivator; (2) guru sebagai pemimpin; (3) guru sebagai problem solver; dan (4) guru sebagai sahabat siswa. Rumusan masalah yang penulis angkat dalam penulisan ini adalah bagaimana bentuk peranan guru sebagai motivator, pemimpin, problem solver dan sahabat siswa dalam memberikan pendidikan kepemimpinan kepada siswa.

Tulisan ini bermanfaat untuk bertambahnya pengetahuan dan wawasan guru, praktisi dan pemerhati pendidikantentang peranan guru dalam memberipendidikan kepemimpinan. Tumbuhnya motivasi dan inisiatif guru dalam meningkatkan ketrerampilan mengajar pendidikan kepemimpinan.

\section{B. Pembahasan}

\section{Guru sebagai Motivator}

Banyak cara yang bisa diterapkan guru dalam memberikan pendidikan kepemimpinan kepada siswa. Namun demikian, apapun cara yang dipakai, satu hal yang harus dipastikan adalah bahwa materi yang disampaikan tersebut bisa diterima dan dimengerti oleh siswa dengan baik, tidak membuat mereka kehilangan semangat belajar, mengantuk atau kehilangan tujuan pembelajarannya. Oleh sebab itu, cara mengajar tersebut haruslah menimbulkan motivasi dan minat yang tinggi dari siswa. Sebagai motivator, guru dituntut menjadi pribadi yang menyenangkan, mengembirakan, menghibur, bisa mengendalikan dan melarutkan emosi siswa dalam pendidikan kepemimpinan yang disampaikannya.

Tidaklah sulit sesungguhnya menjadi guru yang motivator bagi siswa, karena pada dasarnya setiap orang adalah motivator terbaik bagi dirinya sendiri, dan selanjutnya tinggal menularkannya kepada orang lain (baca: siswa) dengan baik pula. Berikut adalah syarat guru sebagai motivator dalam memberikan pendidikan kepemimpinan (Hendra Riofita, 2014): 
a. Memperhatikan penampilan

Guru sebaiknya menyesuaikan penampilannya dengan siswa. Sebagai seorang motivator, menempatkan penampilan yang sesuai dengan siswa adalah sebuah keharusan bagi guru. Penampilan yang tepat akan menunjang keyakinan para siswa terhadap pendidikan kepemimpinan yang diberikan. Walau bagaimanapun, kesan pertama yang menggoda dari seorang guru bisa didapatkan siswa dari penampilan guru tersebut. Akan sangat sulit bagi siswa menerima input tentang pendidikan kepemimpinan dari guru yang penampilannya tidak meyakinkan, sekalipun input itu sesungguhnya sangat berharga.

b. Dikenal dan disukai siswa

Mengacu pada konteks public relations, ada tiga tipe siswa yang ditemui guru dalam kegiatan belajar mengajarnya, yaitu siswa yang kenal guru dan menyukai guru tersebut; siswa yang kenal guru tapi tidak menyukai guru tersebut; dan siswa yang tidak kenal guru sehingga tidak peduli dengan guru tersebut. Oleh sebab itu, dalam waktu yang singkat, diawal pembelajaran tentang pendidikan kepemimpinan, guru sebaiknya membuat ice breakingyang berkaitan tentang pendidikan kepemimpinan tersebut namun sekaligus bisa menyatukan dirinya dengan siswa, dan membuat mereka semua suka kepada dirinya. Jangan pernah berharap siswaakan bisa termotivasi belajar dengan guru yang tidak disukai atau yang tidak dipedulikan. Oleh sebab itu, permainan-permainan komunikatif atau cerita-cerita motivasi berikut brain storming yang diarahkan penekananannya pada materi kepemimpinan yang akan diberikan, adalah langkah-langkah ice breaking yang bisa dilakukan oleh guru untuk menonjolkan performancenya membuat dikenal dan disukai oleh siswa.

c. Berkomunikasi efektif

Komunikasi adalah sarana yang dipakai oleh guru dalam memberikan pendidikan kepemimpinan kepada siswa. Semua orang bisa berkomunikasi tapi tidak semua orang bisa berkomunikasi efektif sehingga bisa diterima oleh lawan bicaranya. Oleh sebab itu, sebagai orang yang akan memberikan pendidikan kepemimpinan, guru sebaiknya menguasai teknik berkomunikasi yang efektif agar mampu menemukan persamaan makna dengan siswa, yaitu memastikan 
bahwa segala materi yang disampaikannya bisa dengan gamblang dan mudah untuk diterima dan dimengerti. Untuk itu, sebelum menyampaikan materi pengajaran, guru sebaiknya terlebih dahulu mengatasi faktor-faktor hambatan yang bisa mengganggu komunikasi efektifnya dengan siswa. Faktor hambatan tersebut di antaranya adalah:

1. Usia

Karena siswa yang belajar usianya lebih muda daripada usia guru, sebaiknya guru menggunakan komunikasi dengan kosa kata dan intonasi yang mengayomi dan menyayangi.

\section{Jenis kelamin}

Bila berbicara kepada siswa wanita, guru sebaiknya menyentuh hatinya dan sebaliknya bila berbicara dengan siswa pria, guru sebaiknya menyentuh logikanya. Dengan demikian, sudah tidak saatnya lagi guru memandang sama antara siswawanita dan pria ketika melakukan komunikasi dengan mereka.

\section{Faktor budaya}

Adalah hal yang baik bagi guru untuk mengenal budaya siswa, karena berkomunikasi dengan siswadari budaya/etnis A tentu akan berbeda dengan siswadari budaya/etnis B. Oleh sebab itu, kemauan guru untuk mempelajari latar belakang budaya/etnis tertentu akan memudahkannya berkomunikasi efektif dengan siswa.

4. Waktu

Sebaiknya guru juga memperhatikan waktu ketika terjadinya komunikasi. Komunikasi yang dilakukan di pagi hari yang masih segar tentu akan berbeda caranya dengan komunikasi yang dilakukan di siang hari yang bernuansa lapar dan mengantuk, dimana siswasebaiknya lebih banyak disegarkan dengan kegiatan-kegiatan aplikatif dan komunikatif tentang kepemimpinan daripada mendengarkan ceramah. Karena itu, kemampuan dalam menimbang waktu, akan membantu guru untuk bisa berkomunikasi efektif dengan siswa.

Bila faktor-faktor yang menghambat untuk terjadinya komunikasi efektif dalam penyampaian pendidikan kepemimpinan dengan siswa di atas bisa diatasi, maka 
selanjutnya guru berkomunikasi sebagai motivator dalam memberikan materi pendidikan kepemimpinan kepada siswa. Adapun teknik komunikasi sebagai motivator tersebut menurut Hendra Riofita (2014) adalah sebagai berikut:

1. Dapatkan perhatian siswa untuk pendidikan kepemimpinan yang diberikan Menggunakan yel-yel atau kata-kata yang menyemangatkan adalah cara yang bisa dilakukan guru untuk mendapatkan perhatian sekaligus menyemangati siswa. Disamping itu, menyampaikan pertanyaan-pertanyaan tentang kepemimpinan yang dapat mengundang rasa ingin tahu lebih mendalam dari siswa, juga dapat dilakukan untuk mendapatkan perhatian mereka tentang materi pendidikan kepemimpinan yang akan didiberikan.

2. Dapatkan ketertarikan siswa untuk pendidikan kepemimpin yang diberikan Setelah perhatian siswa didapatkan, rubahlah perhatian mereka tersebut menjadi ketertarikan terhadap pendidikan kepemimpinan yang diberikan. Menggunakan alat peraga, memainkan permainan yang komunikatif atau menampilkan cerita-cerita kepemimpinan yang juga komunikatif berikut brain storming nya adalah langkah-langkah yang bisa dilakukan guru untuk mendapatkan ketertarikan siswa. Bila ketertarikan siswaini sejatinya sudah didapatkan, maka tugas guru selanjutnya adalah melanjutkan konsistensinya dalam menjaga ketertarikan mereka melalui kegiatan belajar mengajar yang mengedepankan learning by doing dan learning by experience dengan pendekatan kedewasaan yang menempatkan siswasebagai subjek aktif dalam proses pembelajaran tentang pendidikan kepemimpinan tersebut.

3. Buat siswa berhasrat untuk mendalami materi tentang pendidikan kepemimpinan.

Setelah guru berhasil mendapatkan ketertarikan siswa dalam belajar pendidikan kepemimpinan, guru selanjutnya harus dapat meningkatkan ketertarikan mereka tersebut menjadi sebuah hasrat untuk mendapatkan pengetahuan yang lebih daripada yang sudah dibahas. Hal ini dapat dilakukan dengan memancing mereka untuk mengajukan pertanyaan-pertanyaan atau pendapat-pendapat yang lebih mendalam tentang materipendidikan kepemimpinan. Semakin banyak pertanyaan atau pendapat yang muncul, bisa 
dipastikan bahwa siswa sangat berhasrat untuk tahu tentang materi pendidikan kepemimpinan tersebut.

4. Arahkan siswa untuk melakukan tindakan sesuai dengan materi pendidikan kepemimpinan yang disampaikan.

Sebagai motivator, guru harus dapat mengarahkan dan menggairahkan siswa untuk melakukan berbagai tindakan praktis yang berkaitan dengan materi pendidikan kepemimpinan yang sudah diberikan. Jika langkah pertama, kedua dan ketiga diatas sudah dilakukan dengan baik, maka langkah terakhir ini adalah langkah pembuktian keberhasilan seorang guru dalam menyampaikan materi tentang pendidikan kepemimpinan.

Setelah syarat dan teknik komunikasi sebagai motivator terpenuhi, guru harus memperhatikan secara khusus tentangmateri pendidikan kepemimpinanyang sesuai dan dibutuhkan oleh siswa. Materi pendidikan kepemimpinan tersebut harus mampu memotivasi siswa untuk bisa berubah secara pola pikir, tingkah laku dan sikap mental yang sejalan dengan standar kompetensi pengetahuan, keterampilan dan sikap yang menjadi tujuan pengajaranpendidikan kepemimpinan. Guru harus menempatkan diri sebagai penyedia fasilitas dan kesempatan untuk terjadinya perubahan tersebut dengan mengemas materi-materi inspiratif dari awal sampai dengan akhir pembelajaran. Oleh sebab itu, guru harus bisa membuat siswaaktif dalam kegiatan belajar mengajar sehingga dari aktivitas yang mereka lakukan, guru dapat mengetahui kharakter mana yang bisa berubah, sedang berubah atau tidak bisa berubah untuk kemudian diambil tindakan tersendiri sebagai langkah lanjutan dari hasil proses belajar mengajar tentang pendidikan kepemimpinan tersebut.

Sebagai motivator bagi siswa dalam belajar pendidikan kepemimpinan, guru harus menjadi model untuk apa yang disampaikannya. Guru dituntut harus bisa memberikan bukti-bukti dan contoh-contoh konkrit terhadap apa yang disampaikannya guna menumbuhkan kepercayaan dan motivasi siswa.

Disamping itu, sebagai wujud dari pendekatan kedewasaan, guru juga tidak boleh menempatkan dirinya sebagai orang yang lebih pintar dari siswa, agar mereka bisa lebih terbuka kepadanya. Keterbukaan siswa akan memudahkan guru untuk memberikan input pengajaran kepada mereka. 
Terakhir, sebagai motivator, guru benar-benar harus mengedepankan kemauan (bukan kemampuan) untuk menularkan materi pendidikan kepemimpinan yang diajarkannya kepada siswasehingga apa dan bagaimanapun kondisi siswayang dihadapi, guru tetap bertanggung jawab penuh untuk bisa membuat mereka berubah sesuai dengan tujuan dan kompetensi pembelajaranpendidikan kepemimpinan.

\section{Guru Sebagai Pemimpin}

Untuk memberikan pendidikan kepemimpinan, guru sendiri tentunya haruslah bersikap dan bertindak sebagai pemimpin ketika memberikan pendidikan kepemimpinan tersebut. Ada banyak alasan yang membuat guru dikatakan sebagai pemimpin didalam kelas dan salah satunya adalah karena guru berperan sebagai dirigen di depan kelas yang mengarahkan dan menuntun siswa mencapai tujuan pembelajaran pendidikan kepemimpinan yang telah ditetapkan. Sebagai pemimpin, guru harus dapat menggugah dan menginspirasi siswa untuk mencapai kompetensi sikap, pengetahuan dan keterampilan dibidang kepemimpinan. Oleh sebab itu, guru merupakan sosok yang digugu dan ditiru alias menjadi suri tauladan bagi para siswanya, sehingga tidak difungsikan untuk mengubah siswa, tapi lebih cocok sebagai agent of change, agar siswa bisa mengubah diri mereka sendiri sebagai akibat dari keteladanan yang telah diberikan.

Selanjutnya, sebagai pemimpin, guru meminimalkan aktivitasnya di dalam kelas dan membuat siswa proaktif dalam mengekspresikan penguasaan mereka terhadap pelajaranmengenai pendidikan kepemimpinan. Guru sejatinya hanya sebagai fasilitator yang bertanggung jawab penuh dalam mengawal aktivitas para siswa untuk kemudian memberikan penilaian yang autentik semenjak proses belajar mengajar dimulai, agar setiap langkah dalam pencapaian tujuan bisa diukur dengan cermat.

Ada beberapa sifat yang harus dipenuhi oleh guru untuk menjadi pemimpin yang dapat memfasilitasi dan menginspirasi para siswa untuk belajar materi pendidikan kepemimpinan (Hendra Riofita, 2014), yaitu:

\section{a. Visioner}

Guru dengan visi yang hebat akan memiliki komitmen dan rasa percaya diri yang tinggi dalam mengemban misi pembelajaran pendidikan kepemimpinan di dalam kelas dan sekaligus akan mampu mengidentifikasi arah dan tujuan 
pembelajaran pendidikan kepemimpinan yang tepat, sehingga selalu bisa fokus dalam pencapaian hasil. Selanjutnya, karena guru merupakan sumber keteladanan bagi siswa untuk berubah, maka guru yang visioner pastinya memiliki kompetensi sikap, pengetahuan dan keterampilan yang tepat dalam pelajaran pendidikan kepemimpinan yang diampunya. Oleh sebab itu, guru yang kompeten, sudah pasti akan menjadi model yang sesuai bagi para siswa untuk meningkatkan kompetensi kepemimpinan mereka.

b. Tangguh

Guru harus memiliki kepribadian pemimpin yang tangguh dan memiliki semangat yang tidak pernah menyerah dalam menularkan keberhasilan bagi siswa. Hal ini bisa dibuktikan dengan kecekatan guru dalam mengambil tindakan. Oleh karena itu, dengan tindakan dan pemikiran yang akurat, guru semestinya selalu bisa mengendalikan dan menciptakan situasi yang tepat bagi para siswa dalam belajar pendidikan kepemimpinan.

c. Batu karang

Guru adalah sosok yang tegar dan sabar seperti batu karang, sehingga bisa menyikapi setiap kesulitan yang ditemuinya sebagai sebuah peluang dalam memberikan pendidikan kepemimpinan. Dengan demikian, guru tidak hanya harus sanggup bertahan dalam setiap kesulitan, tapi juga harus bisa mengatasinya dengan baik agar pekerjaannya sebagai pendidik bisa dituntaskan. Untuk hal ini, tentu saja sikap yang bersungguh-sungguh dan penuh cinta terhadap pekerjaan merupakan hal konkret yang harus dimiliki oleh guru.

d. Rendah hati

Guru tidak membuat murid minder untuk bertukar pikiran tentang pendidikan kepemimpinan yang diberikannya. Agar hal ini bisa dengan mudah diwujudkan, sebaiknya guru tidak lagi menempatkan siswasebagai orang yang memiliki tingkat pengetahuan dan keterampilan yang lebih rendah daripada yang dimilikinya, tetapi justru menempatkan mereka sebagai mitra yang sejajar dalam berdiskusi dan bertukar fikiran. 
e. Pembaca Berita di Televisi.

Guru sebaiknya bisa seperti pembaca berita di televisi yang yang bisa menyampaikan banyak pesan secara jelas kepada siapapun. Karena itu, selain mengasah kemampuan berkomunikasi yang efektif, guru juga dituntut untuk bisa memiliki banyak wawasan, pengetahuan dan gagasan tentang pendidikan kepemimpinan. Disamping itu, seperti pembaca berita di televisi, guru sebaiknya juga mengemas diri dan dan materi pendidikan kepemimpinannya dengan menarik pula. Guru dengan materi pelajaran yang tidak menarik akan dengan mudah membuat siswa bosan, dan kebosanan itu tentu akan mendekatkan siswa pada kegagalan.

f. Komputer

Guru harus seperti komputer yang memiliki kemampuan berfikir yang cepat dan tepat agar segala permasalahan yang muncul dalam memberikan pendidikan kepemimpinan dapat diselesaikan dengan cepat dan tepat pula.

g. Palang merah

Guru harus bisa juga seperti palang merang merah yang selalu siap hadir membantu siswa keluar dari setiap kerumitan dan permasalahan yang dihadapi dalam mengikuti pendidikan kepemimpinan.

h. Kembang api

Guru harus bertindak seperti kembang api yangbersinar terang benderang di kegelapan malam ketika mengajarkan materi pendidikan kepemimpinan agar kebahagian dan keceriaan bisa ditaburkan kepada siswa sepanjang proses pembelajaran.

i. Salesman

Guru harus bisa menjadi salesman yang selalu menawarkan ide dan gagasan yang cemerlang ketika memberikan pendidikan kepemimpinan kepada siswa.

j. Semut

Guru harus bisa menjadi seperti seekor semutdalam hal kekompakan dan kerjasama, artinya, guru harus bisa menciptakan kerjasama dan iklim interaksi yang kompak dengan siswa ketika memberikan pendidikan kepemimpinan. 
k. Kreatif dan inovatif

Guru dituntu memikliki kreativitas dan inovasi yang tinggi dalam menjalankan aktivitas-aktivitasnya sebagai pengajar untuk materi pendidikan kepemimpinan karena guru yang kreatif dan inovatif akan selalu memunculkan nuansa baru yang menyegarkan sehingga penyampaian materi pendidikan kepemimpinan tersebut menjadi tidak membosankan bagi siswa.

1. Pelayan

Guru harus bertindak sebagai pelayan yang prima bagi para siswanya dalam mempelajari materi pendidikan kepemimpinan yang diberikan agar segala kebutuhan dan kesulitan siswa dalam belajar tersebut bisa difasilitasi dengan baik.

\section{Guru Sebagai Problem Solver}

Seperti yang sudah disampaikan pada latar belakang pendahuluan, semua manusia tanpa terkecuali termasuk para siswa di sekolah terlahir sebagai pemimpin. Sayangnya potensi mereka sebagai pemimpin tersebut tanpa disadari sering tenggelam akibat pengaruh pengaruh lingkungan. Lingkungan yang tidak tepat, sering membuat para siswa terperangkap dalam permasalahan yang bila tidak diatasi sedari awal, tidak hanya akan membunuh potensi kepemimpinan mereka, tapi lebih jauh dari pada itu, juga dapat menjadikan pribadi mereka menjadi pribadi yang tidak mumpuni bagi masa depan bangsa. Oleh sebab itu, sekolah sebagai salah satu lingkungan utama yang memainkan peranan dalam manjaga, menumbuhkan dan mengembangkan potensi kepemimpinan tersebut, sebaiknya selalu memacu siswa dalam mengembangkan potensi kepemimpinan mereka melalui proses belajar mengajar di dalam kelas yang diampu oleh para guru. Guru harus berkelanjutan membentuk dan membangun kharakter kepemimpinan tersebut dengan menciptakan pribadi-pribadi yang kritis dan kreatif melalui pelajaran-pelajaran pendidikan kepemimpinan yang mengedepankan problem solving, seperti studi kasus, diskusi, debat, dan brain storming. Dengan demikian, bila penguasaan pelajaran pendidikan kepemimpinan didapatkan melalui problem solving, maka setuju atau tidak, gurupun dituntut untuk berperan sebagai problem solver yang membantu siswa untuk menguasai dan mengimplementasikan hasil dari pelajaran pendidikan kepemimpinan yang diberikan. 
Lebih jauh, sebagai problem solver, guru tentunya juga dapat membedakan kharakter yang seharusnya lekat pada para siswa, dengan kharakter yang sedang mereka jalani, karena pada hakekatnya, kharakter yang ada dan yang sedang mereka jalani belum tentu pantas untuk pekembangan dan kebaikan mereka sebagai pemimpin dimasa depan. Oleh karena itu, sebagai problem solver, dalam authentic assessment yang dipedomani dari kurikulum 2013, guru tidak akan mencari benar atau salah terhadap sikap perilaku siswa, tapi akan menilai dan mengarahkan sikap dan perilaku mana yang seharusnya menjadi kharakter kepemimpinan mereka.

Jelaslah sekarang, menjadi problem solver bukanlah sebuah keharusan tapi kewajiban yang seharusnya sudah melekat pada identitas diri seorang guru. Menjadi problem solver tentu membutuhkan keterampilan tersendiri yang terkadang tidak harus di dapat dari forum-forum formal tapi juga bisa didapat dari forum-forum non formal. Tindakan mengamati perilaku dan tingkah laku para pemimpin, para senior (termasuk guru senior dan kepala sekolah) atau orang tua di rumah, untuk kemudian berkeinginan mempelajari segala hal-hal positif dari mereka (terutama dalam hal-hal yang berkaitan dengan problem solver) adalah cara mudah dan bermanfaat bagi seorang guru dalam menjadi problem solver untuk para siswanya. Semua permasalahan besar dan kecil, yang terjadi di lingkungan dan kehidupan yang dijalani, adalah ajang latihan yang tepat bagi guru untuk belajar dan berlatih menjadi problem solver yang handal.

Berikut adalah langkah-langkah yang dapat dilakukan oleh guru untuk menjadi problem solver bagi para siswa dalam belajar pendidikan kepemimpinan (Hendra Riofita, 2014):

a. Tentukan dan definisikan permasalahan siswa dengan tepat dalam mempelajari pendidikan kepemimpinan.

Salah dalam menentukan dan mendefinisikan permasalahan tentu akan salah dalam memberikan solusi. Bila hal ini terjadi, selain masalah siswa tidak akan pernah terpecahkan, juga akan bisa menimbulkan permasalahan yang baru bagi siswa atau bahkan bagi guru sendiri. Karena itu, pendekatan yang tidak reaktif terhadap penyelesaian masalah, teruslah dikembangkan seiring peningkatan kedewasaan yang mengikuti pertambahan usia guru. Jika diperlukan, tidak ada salahnya bila guru menuliskan secara rinci tentang 
beberapa rumusan dan ruang lingkup dari permasalahan yang akan diselesaikan.

b. Bangunlah kesepakatan dengan pihak-pihak yang dipandang harus terlibat dalam penyelesaian masalah siswa tentang pendidikan kepemimpinan.

Berperan seperti layaknya seorang dokter yang mendapatkan kepercayaan penuh untuk menyembuhkan pasien, tentu menjadi tugas utama guru agar legitimasi dalam menyelesaikan masalah tidak mendapatkan resistensi. Jika dipandang perlu, maka ajaklah para pihak tersebut untuk ikut aktif dalam menyelesaikan masalah melalui pembagian peranan, agar dukungan yang didapat dari mereka nyata adanya.

c. Buatlah rencana pemecahan masalah tentang pendidikan kepemimpinan dengan berbagai macam alternatifnya.

Semakin berat permasalahan siswa yang akan dipecahkan, tentu harus semakin bijak dalam menyusun langkah-langkah solusi bagi setiap alternatif tersebut. Terhadap alternatif-alternatif yang disusun, sebaiknya guru mendasarkannnya pada tingkat resiko yang akan diambil, biaya yang akan dikeluarkan, waktu yang akan diperlukan dan hal-hal penting yang lainnya.

d. Melakukan simulasi terhadap semua alternatif solusi yang sudah dibuat. Agar tingkat keberhasilan dari solusi yang dipilih benar-benar bisa meminimalkan atau menghilangkan resiko, berbiaya murah baik secara materi maupun non materi, tidak menghabiskan energi, dan yang pasti, solusi itu tepat dan tidak mendatangkan masalah yang baru, maka guru sebaiknya melakukan simulasi terhadap semua alternatif solusi mengenai permasalahan siswa tentang pendidikan kepemimpinan.

e. Tentukan solusi dan segera untuk mengimplementasikannya dalam memberikan pendidikan kepemimpinan.

Keberhasilan solusi tidak bisa diharapkan terjadi begitu saja, tapi harus diukur efektifitasnya pada setiap langkah yang dilakukan. Karena itu, kemauan semua pihak yang memegang peranan dalam penyelesaian masalah untuk melakukan pengendalian terhadap apa yang dilakukan, merupakan sebuah keharusan. Jadi, semakin banyak pihak yang diberi peranan oleh guru dalam 
penyelesaian masalah tersebut, maka semakin banyak pulalah pihak-pihak yang harus dipantau dan dinilai oleh guru tentang keefektifitasan langkah mereka.

f. Tidak ada masalah yang tidak bisa diselesaikan.

Guru adalah tempat bergantungnya para siswa untuk meraih masa depan mereka sebagai pemimpin yang cemerlang dan gemilang bagi kepentingan nusa, bangsa dan agama. Adalah kewajiban guru untuk menjadi problem solver bagi para siswanya dalam setiap kondisi yang ada, tanpa terkecuali. Oleh karena itu, hanya semangat yang tidak pernah pudarlah yang akan membuat guru bisa menjadikan siswa lebih hebat daripada dirinya, termasuk dalam hal menjadi problem solver.

\section{Guru Sebagai Sahabat Siswa}

Sahabat adalah orang yang dengannya seseorang menjadi pribadi yang memiliki arti dan tempat untuk saling berbagi. Dengan sahabat seseorang memiliki kebebasan untuk berekspresi yang terkadang tidak berbatas tapi mampu untuk saling memahami dan menghargai. Dengan sahabat seseorang bisa menunjukkan jati diri yang sebenarnya tanpa dikhawatirkan oleh hal-hal yang akan menjatuhkan integritas diri. Ringkasnya, sahabat adalah orang terpercaya yang bisa memahami diri seseorang apa adanya dalam segala situasi.

Pada profesi apapun juga yang dilakoni, tidak terkecuali pada profesi sebagai seorang guru, alangkah indah dan mudahnya hidup ini bila bisa bersahabat dengan siapa saja termasuk dengan para siswa. Bersahabat dengan para siswa tentu akan mampu membuat tujuan dari proses belajar mengajar, termasuk tujuan dalam pemberian pendidikan kepemimpinan yang dilakukan guru, akan menjadi lebih mudah untuk dicapai.

Berikut adalah langkah-langkah yang dapat dilakukan oleh guru untuk bisa menjadi sahabat bagi para siswa dalam memberikan pendidikan kepemimpinan (Hendra Riofita, 2014):

a. Mengenal kharakter siswa

Siapapapun orangnya, hanya bisa bersahabat dengan orang yang dikenal dan bisa diterima kharakternya. Oleh sebab itu, bagi guru, berusaha menjadi 
kharakter yang dikenal dan disukai oleh siswa adalah sama wajibnya dengan berusaha untuk mengenal dan menyukai kharakter siswa itu sendiri. Dengan kata lain, hanya dengan saling mengenal kharakter lah jalinan interaksi ala orang bersahabat dapat dilakukan guru dengan siswa sehingga penyampaian pendidikan kepemimpinan dapat dilakukan melalui interaksi yang lebih mudah. Namun demikian, harus diakui bahwa dengan latar belakang siswa yang tidak homogen, tentu tidak mudah bagi guru untuk mengenal kharakter siswa secara satu persatu. Oleh sebab itu, penguasaan akan psikologi anak dalam pendidikan, mau tidak mau seyogyanya haruslah dikuasai oleh guru dengan baik agar bisa memberikan materi pendidikan kepemimpinan yang tepat dan sesuai bagi setiap kharakter siswa.

b. Kemampuan berkomunikasi yang efektif

Seorang sahabat akan selalu didengar omongannya, karena itu, apapun yang dikatakan oleh seorang sahabat, akan selalu efektif untuk bisa diterima. Hal ini disebabkan karena ketika menyampaikan sesuatu hal, seorang sahabat selalu mengedepankan sisi empati dan simpati alias bisa menempatkan diri pada posisi lawan bicaranya. Jadi, karena komunikasi merupakan sarana bagi guru untuk berinteraksi dengan siswa dalam memberikan pendidikan kepemimpinan, sudah selayaknyalah guru juga mengedepankan sisi empati dan simpati ketika berbicara kepada siswa, tidak hanya ketika menyampaikan pendidikan kepemimpinan, tapi juga ketika berbagi dan menggali potensi siswa mengenai kepemimpinan itu sendiri, baik didalam maupun di luar kelas. Oleh sebab itu, kemampuan guru untuk berkomunikasi yang efektif layaknya seperti seorang sahabat yang berbicara, haruslah dikedepankan agar makna kepemimpinan yang disampaikan bisa dengan efektif diterima siswa. Semakin efektif cara guru berkomunikasi dengan siswa, akan semakin mudah bagi guru untuk memahami kebutuhan siswa. Semakin guru memahami kebutuhan siswa akan semakin mudah pula untuk mengarahkan mereka dalam mencapai tujuan pembelajaran pendidikan kepemimpinan.

c. Membangun kepercayaan 
Seorang sahabat selalu bisa dipercaya dan diandalkan untuk berbagi tentang hal apa saja, termasuk tentang hal yang sangat privacy sekalipun. Oleh sebab itu, seorang sahabat akan selalu menjaga integritas yang sudah dibangunnya agar tetap bisa dipercaya. Dengan demikian, bilalah seorang guru ingin menempatkan dirinya sebagai sahabat siswa, maka tentu guru seyogyanya menjaga integritas agar selalu bisa dipercaya. Karenanya, selalu bisa menjadi tauladan terhadap apa yang disampaikan, jujur dalam berkata-kata, amanah dalam mengelola hal-hal yang bersifat privacy, adalah contoh hal yang bisa dilakukan guru untuk membangun kepercayaan sebagai sahabat bagi siswa. Bila hal ini dilakukan, maka bisalah dipastikan bahwa siswa akan terbuka kepada gurunya tentang segala hal terutama tentang hal-hal yang menghambat pencapaian tujuan pembelajaran pendidikan kepemimpinan untuk kemudian bisa diambil langkah-langkah yang tepat bagi guru dalam memberi solusinya.

d. Membangun kerjasama

Tidak bisa diingkari bahwa sesungguhnya setiap orang selalu mencari orangorang yang bisa dipercaya untuk diajak bekerjasama. Karena itu, semakin dekat hubungan seseorang akan semakin mudahlah untuk bisa dipercaya dalam bekerjasama. Kedekatan hubungan alias kekerabatan tidak hanya bisa dibangun dalam keluarga tapi juga bisa dengan orang lain yang sudah dipercaya, dan orang lain tersebut salah satunya sering ditemui dalam wujud sahabat. Dengan sahabat, seseorang bersedia jatuh bangun dalam berusaha, rela berkorban dan mengambil resiko bagi kepentingan bersama. Semakin hebat bangunan sebuah persahabatan, maka semakin hebat pula bangunan kerjasama yang akan terbentuk.

Di sekolah, guru dan siswa tidak bisa jalan sendiri-sendiri dalam menyukseskan tujuan pembelajaran pendidikan kepemimpinan. Mereka harus menjalankan fungsi masing-masing dan siap mempertanggung jawabkannya pada cara dan pola yang sudah ditetapkan guna mencapai tujuaan pembelajaran pendidikan kepemimpinan tersebut. Oleh karena itu, guru dan siswa harus bersatu dalam bangunan kerjasama yang solid, minimal 
mencontoh bangunan kerjasama seperti yang diuraikan diatas. Selalu menjadi orang yang visioner, berjiwa kepemimpinan yang handal dan bisa menjadi problem solver adalah hakekat kepribadian yang sebaiknya dimiliki guru sebagai modal utama dalam membangun, mengarahkan, mempertahankan dan mengembangkan kerjasama yang bersahabat dengan siswa dalam menyukseskan tujuan pembelajaran pendidikan kepemimpinan.

e. Selalu berupaya menjaga kebersamaannya dengan siswa, baik secara formal maupun non formal, baik di sekolah maupun di luar sekolah

Hanya dengan kebersamaan yang terjagalah persahabatan bisa langgeng. Selalu menyediakan waktu untuk berinteraksi dengan siswa, selalu mencari celah untuk bisa berkomunikasi dengan siswa, selalu memasukkan unsurunsur edukasidalam setiap interaksi dengan siswa, adalah beberapa cara yang bisa dilakukan guru untuk menjaga kebersamaan yang bersahabat dengan siswa sehinggga pemberian pendidikan kepemimpinan bisa dilakukan setiap saat.

\section{Simpulan dan Saran}

\section{Simpulan}

a. Setiap manusia tidak terkecuali manusia Indonesia, terlahir sebagai pemimpin, karena itu setiap orang di negeri ini berhak diasah kepemimpinannya sedini mungkin dan guru memiliki kewajiban untuk pemenuhan hak tersebut.

b. Banyak bentuk peranan yang dapat dilakukan guru dalam memberikan pendidikan kepemimpinan kepada siswa diantaranya adalah berperan sebagai motivator, pemimpin, problem solver dan sahabat bagi siswa.

\section{Saran}

a. Guru sebaiknya tidak lagi menjadikan siswa sebagai objek untuk penyampain materi pendidikan kepemimpinan tetapi menjadikan mereka mitra sejajar yang memiliki tanggung jawab yang sama dengan dirinya untuk menyukseskan tujuan pembelajaran pendidikan kepemimpinan tersebut. 
b. Dalam menjalankan peranan sebagai motivator, pemimpin, problem solver dan sahabat siswa dalam memberikan pendidikan kepemimpinan, guru sebaiknya memakai pendekatan kedewasaan, learning by doing dan learning by experience agar siswa dapat mengeluarkan segala potensi yang mereka miliki untuk kemudian dibenarkan bila belum benar dan ditingkatkan bila sudah benar.

\section{Daftar Pustaka}

Cambel, Linda, Bruce, Dickinson. 2004, Metode Praktis Pembelajaran.Jakarta: Intuisi Press

Dryden Gordon \& Vos Jeannette. 2000. Revolusi Cara Belajar. Bandung: Kaifa

Hendra Riofita. 2014. Padamu Pahlawan Tanpa Tanda Jasa (Menjadi Guru Ideal). Peknabaru: PT. Subentra

James M. Kouzes dan Barry Z. Posner.Leadership Learning. Yogyakarta: Pustaka Baca

K.H. Toto Tasmara. 2002. Membudayakan Etos Kerja Islami, Jakarta: Gema Insani Munandar, S. C. U. 1999. Mengembangkan bakat dan kreativitas anak sekolah.Jakarta:PT.Gramedia.

Nasution, S. 2003. Berbagai Pendekatan dalam Proses Belajar dan Mengajar. Jakarta: Bumi Aksara.

Nugroho, Riant. 2008. Kebijakan Pendidikan yang Unggul. Yogyakarta: Pustaka Pelajar

PEGG, Mike. 1994. Kepemimpinan Positif. Jakarta: Pustaka Binaman Pressindo.

Ramayulis. 2002. Ilmu Penddikan Islam. Jakarta: Kalam Mulia

Rohmat. 2010. Kepemimpinan Kependidikan Konsep dan Aplikasi. Purwokerto: STAIN Press.

Sukmadinata, Nana Syaodih. 2005. Landasan Psikologi Proses Pendidikan. Bandung: PT Remaja Rosdakarya.

Wina Senjaya. 2008. Strategi Pembelajaran; Berorientasi Standar Proses Pendidikan. Jakarta: Kencana Prenada Media Group. 
